\title{
RESTORASI POLITIK LEGISLASI PEMBENTUKAN PERATURAN DAERAH BERBASIS RISET
}

(Restoration of Politics Legislation Establishment of Local Regulation Based Research)

\author{
Ria Casmi Arrsa \\ Pusat Pengembangan Otonomi Daerah (PPOTODA) Universitas Brawijaya \\ Gedung Munir Lantai II Fakultas Hukum Universitas Brawijaya \\ JI. MT. Haryono Nomor 169 Malang Kodepos 65145 Jawa Timur \\ Email: ppotoda@gmail.com
}

Naskah diterima: 7 November 2013; revisi: 11 November 2013; disetujui: 25 November 2013

\begin{abstract}
Abstrak
Potret pembentukan peraturan daerah di tingkat provinsi atau kabupaten/kota merupakan bagian yang tidak terpisahkan dari kewenangan konstitusional yang dimiliki oleh pemerintahan di daerah (amanat Konstitusi Pasal 18 Ayat 6) dalam menjalankan roda pemerintahan di tingkat lokal. Banyak kemajuan yang telah dicapai dalam proses legislasi, namun secara empiris masih ditemukan berbagai celah kelemahan sehingga menyebabkan peraturan daerah dimaksud menjadi tidak efektif dan implementatif. Hal tersebut disebabkan lemahnya pemahaman pembentuk peraturan dalam merumuskan norma hukum dalam peraturan daerah dan juga belum adanya pelembagaan budaya riset melalui naskah akademik yang bersifat satu-kesatuan dalam proses perumusan sampai pada tahap pertanggung jawaban akademik. Sehingga permasalahan adalah apakah yang menjadi dasar urgensi kedudukan riset akademik dalam proses penataan politik legislasi pembentukan peraturan daerah, kemudian bagaimana pertanggung jawaban akademik yang sebagai upaya penataan (restorasi) politik legislasi pembentukan peraturan daerah. Dengan menggunakan metode penelitian yuridis normatif dengan pendekatan peraturan perundang-undangan dan pendekatan konsep, didapatkan kesimpulan bahwa pasca penetapan Undang-Undang Nomor 12 Tahun 2011 tentang Pembentukan Peraturan Perundang-Undangan maka pelembagaan Naskah Akademik mutlak diperlukan untuk melahirkan peraturan daerah yang partisipatif dan berkelanjutan, sehingga dampak positifnya adalah peningkatan kesejahteraan masyarakat di era otonomi daerah.
\end{abstract}

Kata Kunci: naskah akademik, peraturan daerah, pertanggung jawaban akademik

Abstract
Implementation of regional autonomy walk faster amid growing public demand for creating a participatory democratic order that the welfare of the people. In an effort to realize the prosperity and independence of the region, establishment of regional regulations portrait at both provincial, district, and the city is an integral part of the constitutional authorities in the area owned by the Government (Constitutional mandate of Article 18 Paragraph 6 ) in running the government at the local level. Many progress has been achieved in legislative process, however empirically found too many gap, causing a variety of local regulation is ineffective and not implementative. It happened due to the lack of understanding of legal drafter in formulating legal norms at regional regulation as well as the absence institutionalization of a research culture through academic draft that is the unity in formulation process up to academic accountability. Therefore,the problems that determined in this paper are (1) what is the basic of urgency academic research in process arrangement of political legislation regional regulation formation, (2) How about academic accountability as an effort to rearrangement political legislation of regional regulation formation. This paper using juridical normative method, with legislation and conceptual approach. The view of writer is that after enacted the law number 12 year 2011 on legislation formation, then the institutionalization of academic draft absolutely needed to delivered of regional regulation that sustainable and participative until the positively impact would be enjoyed for improving social welfare in authonomy regional era. Keywords : academic paper, local regulations, academic accountability 


\section{A. Pendahuluan}

Perubahan paradigma dan sistem ketatanegaraan yang sentralistik menuju ke arah konsep bernegara yang desentralistik berimplikasi pada kelahiran otonomi daerah sebagai tuntutan dalam merespon pemerataan pembangunan dan peningkatan kesejahteraan rakyat. Gagasan Otonomi daerah dalam pengertian politikdiartikansebagaihakmengatur sendiri kepentingan intern daerah/organisasinya menurut peraturan sendiri. ${ }^{1}$ Kelahiran Otonomi daerah diberikan dengan harapan agar setiap daerah dapat mengelola dan mengatur sendiri daerahnya sesuai dengan karakteristik daerahnya masing-masing. Walaupun tiap daerah diberikan kebebasan dalam mengatur dan menjalankan pembangunan daerahnya, akan tetapi kebebasan tersebut tetap dibatasi oleh keberlakuan yuridis peraturan-peraturan perundang-undangan yang ada diatasnya (lex superior derogat lex inferior). ${ }^{2}$

Menurut Solichin Abdul Wahab, hakikat otonomi daerah adalah kemampuan menyediakan ruang publik yang lebar bagi munculnya partisipasi masyarakat didalamnya, tidak hanya secara pasif dimana partisipasi tersebut ditentukan oleh struktur kekuasaan diatasnya (dan itu bukanlah partisipasi, tetapi mobilisasi), juga secara aktif dimana masyarakat memahami sepenuhnya atas kebutuhan-kebutuhannya, kemudian memilih, merumuskan dan mengupayakan agar dapat tercapai. ${ }^{3}$ Selain itu menurut Abdul Ghofar, otonomi daerah merupakan penerapan konsep teori area/division of power yang membagi kekuasaan negara secara vertikal, sehingga menimbulkan adanya kewenangan penyelenggaraan pemerintahan di suatu sisi oleh pemerintah pusat, sedangkan disisi lain dilaksanakan oleh pemerintah daerah. ${ }^{4}$

Secara kontekstual pada prinsipnya, kebijakan otonomi daerah dilakukan dengan mendesentralisasikan kewenangankewenangan yang selama ini tersentralisasi di pemerintah pusat. Dalam proses desentralisasi itu, kekuasaan pemerintah pusat dialihkan dari tingkat pusat ke pemerintahan daerah sebagaimana mestinya, sehingga terwujud pergeseran kekuasaan dari pusat ke daerah kabupaten dan kota di seluruh Indonesia. Jika dalam kondisi semula arus kekuasaan pemerintahan bergerak dari daerah ke tingkat pusat, maka diidealkan bahwa sejak diterapkannya kebijakan otonomi daerah itu, arus dinamika kekuasaan akan bergerak sebaliknya, yaitu dari pusat ke daerah. ${ }^{5}$

Salah satu bentuk manifestasi kemandirian daerah dalam rangka mengembangkan inovasi dan kreativitas pembangunan di tingkat Provinsi, Kabupaten, Kota memiliki adalah kewenangan

B.N Marbun, Kamus Politik (Jakarta: Pustaka Sinar Harapan, 2007), hlm. 350.

Ria Casmi Arrsa, dkk, Teori dan Hukum Perancangan Perda (The Turning Point Of Legal Paradigm on Sustainaible Development) (Malang: UB Press, 2012), hlm. 35.

3 Solichin, A, Wahab, Masa Depan Otonomi Daerah (Kajian Sosial, Ekonomi, Politik, Untuk Menciptakan Sinergi Dalam Pembangunan Daerah) (Surabaya: Penerbit SIC, 2002), hlm. iii.

4 Adbul Gafur Karim, Kompleksitas Persoalan Otonomi Daerah di Indonesia (Yogyakarta: Pustaka Pelajar, 2003), hlm. 76.

5 Jimly Asshidiqie, "Otonomi daerah dan Parlemen di daerah" (makalah disampaikan dalam Lokakarya tentang Peraturan Daerah dan Budget Bagi Anggota DPRD se-Propinsi (baru) Banten" yang diselenggarakan oleh Institute for the Advancement of Strategies and Sciences (IASS), di Anyer, Banten, 2 Oktober 2000). 
konstitusional untuk membentuk suatu peraturan daerah dalam menjabarkan praktekpraktek kebijakan pembangunan di tingkat lokal. Hal tersebut sebagaimana diamanatkan Pasal 18 ayat (6) UUD NRI Tahun 1945 yang menyebutkan bahwa, "Pemerintahan daerah berhak menetapkan peraturan daerah dan peraturanperaturan lain untuk melaksanakan otonomi dan tugas pembantuan".

Banyak kemajuan-kemajuan dalam bidang otonomi daerah maupun penyelenggaraan pembentukan legislasi di daerah baik dalam bidang pelayanan publik, perekonomian, pendidikan, kesehatan, lingkungan hidup, pertanian, kelautan dan lain-lain. Namun demikian ditengah situasi dan kondisi yang kian dinamis nampaknya praktek-praktek kelemahan pembentukan legislasi di daerah masih menunjukkan adanya ketimpangan tatkala produk hukum daerah yang dihasilkan belum mencerminkan relasi antara perspektif teoritik dalam ranah politik maupun hukum dengan realitas empiris derajat kebutuhan maupun dasar urgensi masyarakat terhadap pembentukan peraturan daerah yang dijalankan oleh pemerintah daerah dan DPRD. Pada konteks tersebut maka problematika produk hukum daerah nampak dari adanya sejumlah pembatalan peraturan daerah (Perda) oleh Kementerian Dalam Negeri (Kemendagri) melalui mekanisme eksekutif review maupun pengujian melalui Mahkamah Agung atau dikenal dengan istilah judicial review.

Pada konteks pengujian (review) dapat dipahami bahwa regulasi di tingkat lokal masih menunjukkan adanya problematika yuridis yang berdampak sistemik dan meluas terhadap penyelenggaraan pemerintahan di daerah. Terhadap pengaturan di tingkat lokal diperlukan kesepahaman bahwa apakah dalam kerangka otonomi daerah di perkenan untuk membentuk Perda secara mandiri ataukah justru otonomi daerah di sandera dengan kebijakan-kebijakan di tingkat pusat yang membatasi daerah dalam membentuk suatu Perda.

Tentunya hal ini telah menjadi perdebatan akademik yang hangat. Penulis mengidentifikasi bahwa ada dua pandangan terkait problematika sebagaimana dimaksud di atas. Perdebatan pertama muncul bahwa tidak semua hal harus diatur dengan Perda. ${ }^{6}$ Pada dasarnya Perda dibentuk dalam rangka penyelenggaraan otonomi, tugas pembantuan dan penjabaran lebih lanjut peraturan perundang-undangan yang lebih tinggi. ${ }^{7}$ Sedangkan pendapat yang kedua adalah bahwa pada dasarnya Perda yang

\footnotetext{
Urusan Pemerintahan yang menjadi urusan Pemerintah menurut Pasal 10 ayat (3) Undang-Undang Nomor 32 Tahun 2004 tentang Pemerintahan Daerah, meliputi (a) politik luar negeri; (b) pertahanan; (c) keamanan; (d) yustisi; (e) moneter dan fiskal nasional; dan (f) agama, Sementara itu ketentuan Pasal 14 ayat (1) Undang-Undang Nomor 32 Tahun 2004 menyatakan bahwa "Urusan wajib yang menjadi kewenangan pemerintahan daerah untuk kabupaten/kota merupakan urusan yang berskala kabupaten/kota meliputi: a, perencanaan dan pengendalian pembangunan; $b$, perencanaan, pemanfaatan, dan pengawasan tata ruang; $c$, penyelenggaraan ketertiban umum dan ketentraman masyarakat; d, penyediaan sarana dan prasarana umum; e, penanganan bidang kesehatan; $f$, penyelenggaraan pendidikan; g, penanggulangan masalah sosial; $h$, pelayanan bidang ketenagakerjaan; i, fasilitasi pengembangan koperasi, usaha kecil dan menengah; $j$, pengendalian lingkungan hidup; k, pelayanan pertanahan; l,pelayanan kependudukan, dan catatan sipil; $\mathrm{m}$, pelayanan administrasi umum pemerintahan; $\mathrm{n}$, pelayanan administrasi penanaman modal; o, penyelenggaraan pelayanan dasar lainnya; dan $\mathrm{p}$, urusan wajib lainnya yang diamanatkan oleh peraturan perundang-undangan,

7 Periksa Pasal 136 UU No, 32 Tahun 2004 khususnya ayat (1), (2), dan ayat (3),
} 
mengatur urusan rumah tangga daerah yang bersumber dari otonomi, jauh lebih luas atau penuh dibandingkan dengan yang bersumber dari tugas pembantuan.

Di bidang otonomi daerah, suatu Perda dapat mengatur urusan pemerintahan yang menjadi wewenang daerah, baik mengenai substansi maupun cara-cara menyelenggarakan urusan pemerintahan tersebut. Sementara di bidang tugas pembantuan, Perda tidak mengatur substansi urusan pemerintahan, melainkan terbatas mengenai cara-cara menyelenggarakan urusan yang memerlukan bantuan. Dalam hal ini daerah memiliki kebebasan sepenuhnya mengatur cara melaksanakan tugas pembantuan. ${ }^{8}$ Selain itu Perda juga bisa mengatur penjabaran peraturan perundang-undangan yang lebih tinggi. Namun demikian penulis berpandangan bahwa hakikat otonomi daerah yang digagas pasca amandemen UUD NRI 1945 adalah dalam rangka untuk mewujudkan partisipasi, mendekatkan masyarakat pada aspek pelayanan publik, sekaligus mendekatkan masyarakat dalam hal ihwal pengambilan kebijakan di tingkat lokal dalam kerangka pembangunan, maka kewenangan daerah dalam membentuk Perda merupakan bentuk kemandirian daerah dalam penyelenggaraan negara dan pemerintahan.

Namun, ditengah keleluasaan daerah dalam menyusun Perda, keprihatinan muncul tatkala ada sejumlah Perda-Perda yang dibatalkan oleh Kementerian Dalam Negeri. Pembatalan Perda dan Peraturan Kepala Daerah merupakan potret buram rendahnya kualitas legislasi di era otonomi daerah. Jumlah perda yang dibatalkan berjumlah sangat banyak. Sebuah data mengenai jumlah pembatalan Perda dan Peraturan Kepala daerah dapat dikemukakan sebagai berikut:

Tabel 1 Jumlah Pembatalan Perda dan Peraturan KDH oleh Pemerintah Pusat ${ }^{9}$

\begin{tabular}{|c|l|l|}
\hline No & \multicolumn{1}{|c|}{ Tahun } & \multicolumn{1}{c|}{ Jumlah } \\
\hline 1 & Tahun 2002 & 19 (Pembatalan) \\
\hline 2 & Tahun 2003 & 105 (Pembatalan) \\
\hline 3 & Tahun 2004 & 236 (Pembatalan) \\
\hline 4 & Tahun 2005 & 126 (Pembatalan) \\
\hline 5 & Tahun 2006 & 114 (Pembatalan) \\
\hline 6 & Tahun 2007 & 173 (Pembatalan) \\
\hline 7 & Tahun 2008 & 229 (Pembatalan) \\
\hline 8 & Tahun 2009 & 715 (Pembatalan) \\
\hline 9 & Tahun 2010 & 3000 (Klarifikasi Perda dan baru diketemukan 407 bermasalah) \\
\hline 10 & Tahun 2011 & 9000 (Klarifikasi Perda dan baru diketemukan 251 bermasalah) \\
\hline
\end{tabular}

Sumber: Kementerian Dalam Negeri 2002-2009 (Data diolah)

I Gede Pantja Astawa, Problematika Hukum Otonomi Daerah di Indonesia (Bandung: Alumni, 2008), hlm. 265266.

9 Lebih lanjut lihat Kementerian Dalam Negeri, http://www,kemendagri,go,id, diakses pada tanggal 10 Oktober 2013. 
Data dalam tabel tersebut menunjukkan banyaknya Perda maupun Peraturan Kepala Daerah bermasalah yang dibatalkan dengan trend terjadi peningkatan pada setiap tahunnya. Informasi lain mengungkapkan bahwa sejak tahun 2000 sampai dengan Desember 2009, Kementerian Dalam Negeri telah membatalkan Perda, yang sebagian besar menyangkut retribusi, pajak daerah, dan perizinan. Sedangkan pada tahun 2010 tercatat 1000 perda lebih telah direkomendasi untuk dibatalkan. Hal senada juga diungkapkan oleh Kementerian Koperasi dan UMKM yang menegaskan bahwa sepanjang 2005-2009, Kementerian Koperasi telah mengevaluasi sebanyak 400 Perda penghambat koperasi.

Dari jumlah sebagaimana dimaksud diatas, sebanyak 211 Perda telah berhasil dicabut dan yang telah diusulkan untuk dibatalkan berjumlah 63 Perda. Adapun jumlah perda yang sedang dibahas oleh Kementerian Dalam Negeri dan Kementerian Keuangan sebanyak 79 Perda. Perda yang diusulkan untuk dibatalkan diantaranya menyangkut permasalahan retribusi, misalnya untuk pengesahan akta pendirian koperasi yang seharusnya tidak dikenai biaya, namun di dalam perda justru pengesahan dimaksud dapat dikenai biaya. Bahkan, ada yang dibuat seperti daftar ulang, sehingga setiap tahun harus membayar, padahal sebenarnya hal tersebut dibiayai oleh pemerintah. Salah satu bentuk pembatalan dimaksud adalah melalui Keputusan Menteri Dalam Negeri Nomor 61 Tahun 2008 tentang Pembatalan Peraturan Daerah Kabupaten Ponorogo Nomor 8 Tahun 2005 tentang Retribusi Bidang Perindustrian, Perdagangan, dan Koperasi.

Berdasarkan data diatas, maka dalam perkembangannya pada tahun 2010,
Kemendagri telah mengklarifikasi pula sekitar 3.000 Perda, dan 407 diantaranya ditemukan bermasalah. Untuk tahun 2011, Kemendagri mengklarifikasi 9000 Perda dan 351 diantaranya ditemukan bermasalah. Perda bermasalah terbanyak terdapat di Sumatera Utara, yaitu sebanyak 217 Perda. Dari data tersebut dapat diketahui bahwa Perda bermasalah menjadi permasalahan yang berulang tiap tahun. Hal ini patut menjadi perhatian mengingat pemerintah setiap tahun telah melakukan upaya evaluasi terhadap pembuatan Perda, namun kemunculan Perda yang bermasalah tersebut terus saja berulang.

Ironisnya, sebagian dari Perda yang bermasalah tersebut masih saja diterapkan di daerah, padahal banyak dari Perda yang bermasalah adalah terkait pajak daerah dan retribusi daerah yang membebani masyarakat. Kehadiran Perda tentang pajak daerah dan retribusi daerah seringkali mengakibatkan ekonomi biaya tinggi karena Perda tersebut mendistorsi aktivitas perekonomian. Tambahan beban biaya pasca program otonomi daerah ini menambah buruk kondisi Indonesia, sehingga tidak kondusif untuk menarik investasi. Kondisi ini menunjukkan lemahnya upaya perbaikan iklim investasi di Indonesia. Jika demikian halnya, maka kehadiran otonomi daerah yang tujuan dan maksud utamanya untuk memberdayakan daerah, termasuk meningkatkan kesejahteraan rakyat, menjadi gagasan yang hanya anganangan saja (utopia).

Sementara itu hasil kajian yang dilakukan oleh KPPOD, memerinci jenis masalah yang terkandung dalam Perda bermasalah. Jenis masalah dimaksud dapat dilihat pada Tabel 2 di bawah ini. 
Tabel 2: Jenis Masalah Dalam Perda Bermasalah ${ }^{10}$

\begin{tabular}{|c|l|c|c|}
\hline No. & \multicolumn{1}{|c|}{ Jenis Pelanggaran/Masalah } & Jumlah & Prosentase \\
\hline 1 & Secara Umum Tidak Bermasalah & 152 & 14,8 \\
\hline 2 & Relevansi Yuridis & 30 & 2,9 \\
\hline 3 & Up to date Acuan Yuridis & 162 & 15,7 \\
\hline 4 & Kelengkapan Yuridis & 58 & 5,6 \\
\hline 5 & Diskoneksi Tujuan dan Isi (Konsistensi Pasal) & 32 & 3,1 \\
\hline 6 & Kejelasan Obyek & 76 & 7,4 \\
\hline 7 & Kejelasan Subyek & 5 & 0,5 \\
\hline 8 & Kejelasan Hak dan Kewajiban Wajib Pungut & 81 & 7,9 \\
\hline 9 & Kejelasan Standar Waktu, Biaya, Prosedur, Struktur Tarif & 234 & 22,7 \\
\hline 10 & Kesesuaian Filosofi dan Prinsip Pungutan & 46 & 4,5 \\
\hline 11 & Keutuhan Wilayah Ekonomi Nasional \& Prinsip Free Internal Trade & 24 & 2,3 \\
\hline 12 & Persaingan Sehat & 9 & 0,9 \\
\hline 13 & Dampak Ekonomi Negatif & 95 & 9,2 \\
\hline 14 & Menghalangi Akses Masyarakat, Perlindungan Lingkungan Hidup & 11 & 1,1 \\
\hline 15 & Pelanggaran Kewenangan Pemerintahan & 15 & 1,5 \\
\hline & Jumlah Perda & 1.030 & 100 \\
\hline
\end{tabular}

Sumber: KPPOD Tahun 2010

Kriteria diatas digunakan oleh KPPOD untuk mengidentifikasi tingkat pelanggaran atau kebermasalahan Perda, yang dikelompokkan menjadi tiga kelompok kebermasalahan, yaitu: (1) Kebermasalahan teknis-yuridis formal (kriteria 2-4); (2) Kebermasalahan substansial (kriteria 5-10); dan (3) Kebermasalahan prinsipil (kriteria 11-15). Menurut kajian yang dilakukan oleh KPPOD (2003) hanya sekitar 14,8\% perda secara umum tidak bermasalah. Selebihnya bermasalah dengan bobot tertinggi pada kejelasan standar waktu, biaya, prosedur, dan struktur tarifnya (22,7\%); acuan yuridisnya $(15,7 \%)$; serta dampaknya yang negatif terhadap ekonomi (9,2\%). Atas dasar kriteria itu, studi KPPOD atas 1.379 Perda pungutan daerah yang diterbitkan oleh Pemerintah Kabupaten/Kota secara jelas dapat dilihat dalam grafik berikut: ${ }^{11}$ 


\section{Gambar 1: Studi terhadap Pembatalan Perda Pajak dan Retribusi}

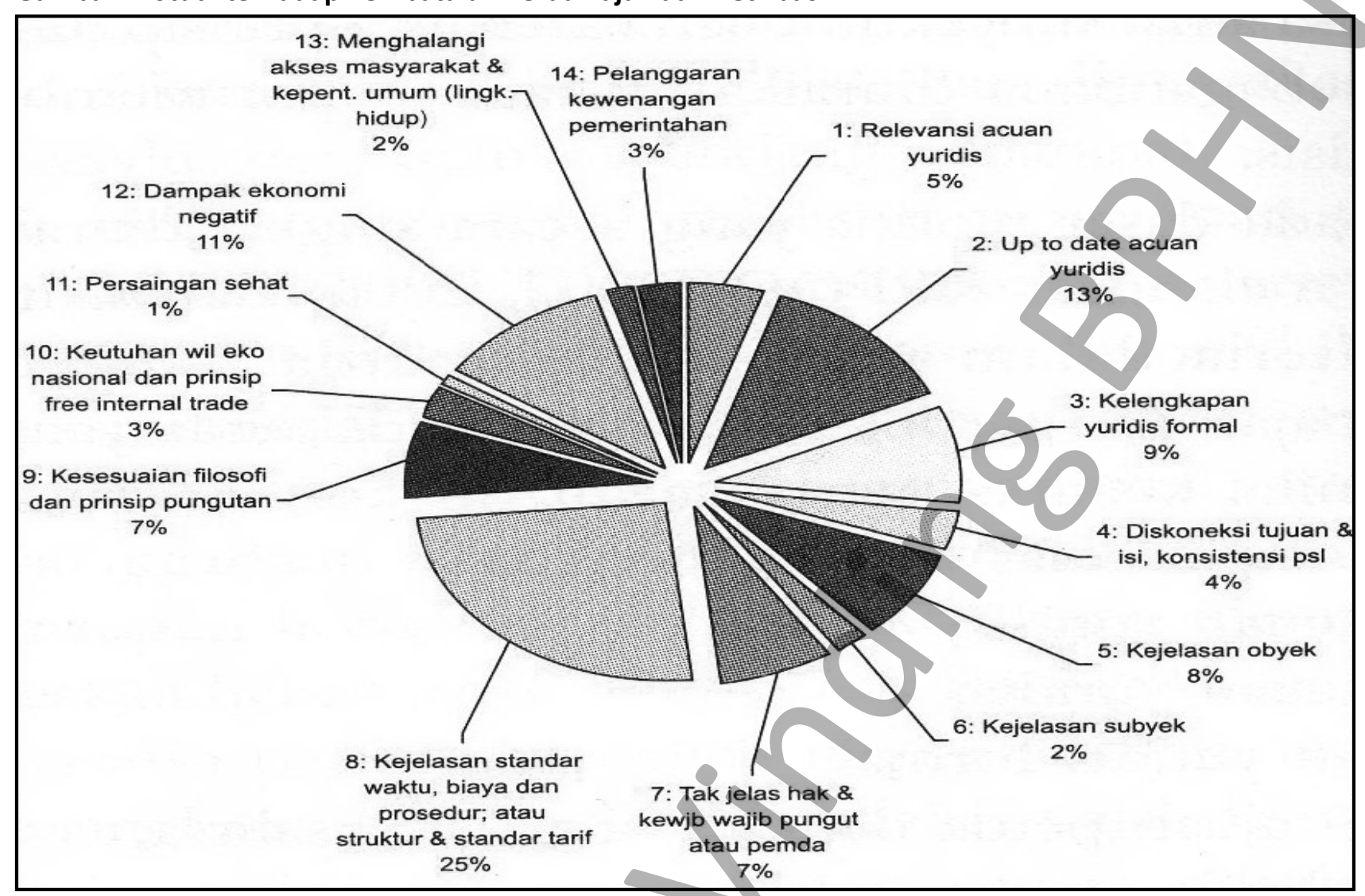

Sumber: KPPOD Tahun 2010

Berdasarkan konteks di atas maka dengan adanya berbagai kesalahan dan kelemahan pembentukan peraturan, maka Perda yang diusulkan akhirnya dibatalkan pemerintah pusat. Jika dirinci, maka Perda yang dibatalkan menyangkut hal-hal sebagimana dalam Tabel 3 berikut ini:

Tabel 3: Perda yang dibatalkan Karena Menghambat Pembangunan Ekonomi dan Masyarakat (s/d Maret 2009) ${ }^{12}$

\begin{tabular}{|c|c|c|c|c|c|c|}
\hline No & Sektor & $2001-2006$ & 2007 & 2008 & 2009 & Jumlah \\
\hline 1 & Administrasi dan Kependudukan & $200+-2000$ & 29 & 57 & 5 & 93 \\
\hline 2 & Energi dan Sumber Daya Mineral & 64 & 104 & 114 & 6 & 288 \\
\hline 3 & Perindustrian dan Perdagangan & 134 & 113 & 136 & 4 & 387 \\
\hline 4 & Kehutanan & 106 & 103 & 81 & 9 & 299 \\
\hline 5 & Kelautan dan Perikanan & 52 & 34 & 39 & 5 & 130 \\
\hline 6 & Kesehatan & 23 & 20 & 46 & 5 & 94 \\
\hline 7 & Ketenagakerjaan & 65 & 22 & 48 & - & 135 \\
\hline 8 & Pekerjaan Umum & 42 & 41 & 51 & 6 & 140 \\
\hline 9 & Komunikasi dan Informatika & 17 & 5 & 12 & - & 34 \\
\hline 10 & Koperasi dan UKM & 59 & 1 & 16 & - & 76 \\
\hline 11 & Lingkungan Hidup & 24 & 18 & 19 & 1 & 62 \\
\hline 12 & Budaya dan Pariwisata & 47 & 77 & 159 & $\frac{1}{9}$ & 292 \\
\hline 13 & Perhubungan & 165 & 132 & 139 & 11 & 447 \\
\hline 14 & Pertanian & 224 & 60 & 58 & 2 & 344 \\
\hline 15 & Sumbangan Pihak Ketiga & 11 & 10 & 12 & - & 33 \\
\hline 16 & Lain-lain & 4 & 4 & 45 & & 53 \\
\hline & Total & 1.039 & 773 & 1.032 & 63 & 2.907 \\
\hline
\end{tabular}

Sumber: KPPOD Tahun 2010.

Dikutip dari Raksaka Mahi, Birokrasi Dan Daya Saing Nasional, Seminar Reformasi Birokrasi: Agenda Pembangunan Nasional 2010-2014, Lihat dalam Moh, Fadli, 2010, "Penguatan Fungsi Legislasi DPRD" (makalah dalam Simposium Nasional Satu Dasawarsa Pelaksanaan Otonomi Daerah diselenggarakan oleh PP-OTODA FH UB, Malang, 1-2 Desember 2010). 
Berdasarkan laporan sebagaimana diuraikan di atas, dibutuhkan adanya sebuah gagasan kritis berkenaan dengan hadirnya paradigma baru dalam penyusunan dan evaluasi terhadap produk hukum di daerah. Kehadiran paradigma baru sebagaimana dimaksud harus mampu menggeser paradigma lama sebagai sebuah keniscayaan dalam rangka mengkonsolidasikan demokratisasi di daerah demi terwujudnya keberlanjutan (sustainability) regulasi yang berjalan secara sinergis dengan tuntutan demokrasi partisipatif di tingkat lokal. ${ }^{13}$

Penulis menawarkan suatu gagasan pembentukan Perda berbasis riset yang dituangkan dalam gagasan Naskah Akademik sebagai dokumen substansial yang dapat dipertanggung jawabkan secara akademik (academic accountabilty) baik dalam proses pengkajian, pembahasan, dan penetapan peraturan daerah sebagai produk hukum yang memiliki kekuatan hukum yang mengikat. Penyusunan Naskah Akademik dimaksud merupakan bagian yang tidak tepisahkan dalam pembentukan Peraturan daerah empiris berdasarkan laporan PPOTODA Universitas Brawijaya $^{14}$ dalam pemetaan legislasi di Jawa Timur memotret bahwa: (1) Sebanyak 80\% dari 38 Kabupaten/Kota di Jawa Timur dalam menyusun peraturan daerah tidak diawali dengan penyusunan Naskah Akademik; (2)
Naskah Akademik sifatnya hanya dijadikan dokumen pelengkap pada saat pembahasan di DPRD sebagai bentuk syarat prosedural formal. (3) Rendahnya kualitas legislasi terutama pada Peraturan Daerah yang bersifat hak inisiatif DPRD karena tidak ditunjang dengan kualitas tenaga ahli perancangan peraturan perundangundangan.

Dengan demikian maka, sudah saatnya gagasan penataan hukum peraturan perundang-undangan didaerah dijalankan dengan mengedepankan riset akademik guna menjemabatani antara ranah politik praksis, kebutuhan masyarakat, lintas keilmuan dengan teori-teori hukum yang bersejalan dengan cita-cita pembangunan bagi peningkatan kesejahteraan rakyat.

\section{B. Permasalahan}

Berdasarkan latar belakang diatas, rumusan permasalahan yang diangkat, yaitu:

1. Apa yang menjadi dasar urgensi kedudukan riset akademik dalam proses penataan politik legislasi pembentukan Peraturan Daerah?

2. Bagaimana Pertanggung jawaban akademik yang sebagai upaya penataan (restorasi) politik legislasi pembentukan Peraturan Daerah? 


\section{Metode Penelitian}

Pengumpulan data dilakukan melalui studi kepustakaan dan literatur, penelusuran informasi perundang-undangan melalui internet, studi penelitian yuridis maupun sosiologis yang dilakukan oleh penulis terkait dengan tema legislasi di daerah maupun mengupas pengalaman penulis dalam proses pendampingan penyusunan Naskah Akademik pembentukan Rancangan Peraturan Daerah di tingkat Provinsi, Kabupaten/Kota di Jawa Timur. Pendekatan penulisan yang digunakan adalah pendekatan peraturan perundang-undangan (statute approach) pasca keberlakuan UndangUndang Nomor 12 Tahun 2011 tentang Pembentukan Peraturan Perundang-Undangan dan pendekatan konsep (conceptual approach) untuk menawarkan gagasan konseptual pembentukan Naskah Akademik yang berkelanjutan.

Penelitian bersifat diskriptif analitis, yaitu menggambarkan analisis hukum mengenai problematika dan peluang bagi penguatan dan peningkatan kualitas legislasi dalam pembentukan Perda di era otonomi daerah. Penelitian ini fokus pada pemetaan legislasi di Provinsi Jawa Timur yang bersejalan dengan program tahunan PPOTODA Universitas Brawijaya untuk melakukan monotoring terhadap perkembangan produk hukum daerah. Harapannya dari telaah dan kajian yang dilakuan dapat dijadikan rekomendasi kebijakan bagi penyempurnaan peraturan perundangundangan mengenai pembentukan peraturan daerah baik di tingkat Provinsi, Kabupaten/Kota.

\section{Pembahasan}

1. Dasar Urgensi Kedudukan Riset Akademik Dalam Proses Penataan Politik Legislasi Pembentukan Peraturan Daerah

Salah satu tuntutan reformasi yang digulirkan sejak tahun 1998 adalah dibangunnya suatu sistem ketatanegaraan Indonesia yang berbasis pada paham kedaulatan rakyat dan negara hukum. Oleh karena itu, dalam konteks penguatan sistem hukum yang diharapkan mampu membawa rakyat Indonesia mencapai tujuan bernegara yang di cita-citakan, maka perubahan Undang-Undang Dasar Negara Republik Indonesia Tahun 1945 (UUD NRI 1945) merupakan langkah strategis yang harus dilakukan dengan seksama oleh bangsa Indonesia. Berbicara tentang sistem hukum tentunya tidak terlepas dari persoalan politik hukum (rechtspolitiek), sebab politik hukumlah yang menentukan sistem hukum yang bagaimana yang dikehendaki. Politik hukum adalah kebijakan dasar yang menentukan arah, bentuk, dan isi hukum yang akan dibentuk. ${ }^{15}$

Kontekstualisasi politik terkait dengan masyarakat dan tujuan yang ingin dicapai oleh masyarakat. Di dalam masyarakat yang telah menegara, sebagian besar dari apa yang menjadi tujuan masyarakat terserap menjadi tujuan negara. Pemilihan tujuan negara dan hukum sebagai cara untuk mencapai tujuan tersebut ditetapkan oleh suatu badan, regulasi atau lembaga yang merepresentasikan seluruh rakyat yang menjadi warga negara. Politik itu

15 Padmo Wahyono, Sistem Hukum Nasional Dalam Negara Hukum Pancasila (Jakarta: CV. Rajawali, 1983), hlm. 99, dikutip dari Ahmad Fadlil Sumadi, Politik Hukum, Konstitusi, dan Mahkamah Konstitusi (Aktualisasi Konstitusi Dalam Praksis Kenegaraan) (Malang: Intrans Publishing: 2013), hlm. 2. 
sendiri adalah aktivitas memilih suatu tujuan dan memilih cara untuk mencapai tujuan. Apabila permasalahan memilih tujuan dan cara untuk mencapai tujuan itu kedua-duanya terkait dengan hukum, seperti memilih tujuan hukum dan hukum apa yang akan dipergunakan untuk mencapai tujuan, semua itu juga termasuk bidang studi politik hukum.

Berdasarkan pemahaman diatas maka proses legislasi sebagaimana diutarakan oleh AV.Dicey merupakan bentuk kompromi kepentingan politik yang saling berbenturan. H.L.A. Hart ${ }^{16}$ berpendapat bahwa ciri khas suatu sistem hukum adalah kumpulan ganda dari peraturan-peraturan. Suatu sistem hukum adalah kesatuan dari peraturan-peraturan primer dan peraturan-peraturan sekunder. Peraturan primer adalah norma-norma perilaku. Sedangkan norma-norma sekunder adalah serangkaian norma untuk memutuskan validitas keberlakuannya. Beranjak dari pengertian tersebut maka, pada dasarnya, fungsi hukum sebagai "sarana pembaharuan masyarakat" (law as a tool of social engeneering) relative masih sesuai dengan pembangunan hukum nasional saat ini, namun perlu juga dilengkapi dengan pemberdayaan birokrasi (beureucratic engineering) yang mengedepankan konsep panutan atau kepemimpinan, sehingga fungsi hukum sebagai sarana pembaharuan dapat menciptakan harmonisasi antara elemen birokrasi dan masyarakat dalam satu wadah yang disebut "beureucratic and social engineering" (BSE). ${ }^{17}$
Mochtar Kusumaatmadja secara cemerlang mengubah pengertian hukum sebagai alat (tool) menjadi hukum sebagai sarana (instrument) untuk membangunan masyarakat. Pokokpokok pikiran yang melandasi konsep tersebut adalah bahwa ketertiban dan keteraturan dalam usaha pembangunan dan pembaharuan memang diinginkan, bahkan mutlak perlu, dan bahwa hukum dalam arti norma diharapkan dapat mengarahkan kegiatan manusia kearah yang dikehendaki oleh pembangunan dan pembaharuan itu. Lebih lanjut Mochtar Kusumaatmadja mengatakan, bahwa: ${ }^{18}$

"Hukum merupakan suatu alat untuk
memelihara ketertiban dalam masyarakat.
Mengingat fungsinya sifat hukum, pada
dasarnya adalah konservatif artinya, hukum
bersifat memelihara dan mempertahankan
yang telah tercapai. Fungsi demikian
diperlukan dalam setiap masyarakat,
termasuk masyarakat yang sedang
membangun, karena di sini pun ada hasil-
hasil yang harus dipelihara, dilindungi dan
diamankan. Akan tetapi, masyarakat yang
sedang membangun, yang dalam difinisi kita
berarti masyarakat yang sedang berubah
cepat, hukum tidak cukup memiliki memiliki
fungsi demikian saja. la juga harus dapat
membantu proses perubahan masyarakat
itu. Pandangan yang kolot tentang hukum
yang menitikberatkan fungsi pemeliharaan
ketertiban dalam arti statis, dan menekankan
sifat konservatif dari hukum, menganggap
bahwa hukum tidak dapat memainkan
suatu peranan yang berarti dalam proses
pembaharuan."

Atas dasar pertimbangan diatas maka cara pandang maupun kepentingan para pengambil kebijakan tentunya memiliki perbedaan yang 
kesemuanya tentu memiliki dasar argumentasi. Pada aspek tersebut maka untuk menjembatani realitas politik praksis dan ranah hukum normatif maupun empiris dibutuhkan adanya suatu sarana yang efektif untuk mengakomodir dua polar pemikiran sebagaimana dimaksud. Dalam proses penyusunan Peraturan Daerah tentunya sarana dimaksud adalah dalam bentuk riset akademik yang dituangkan dalam Naskah Akademik agar perdebatan politk dan hukum, pertimbangan kebijakan, kondisi obyektif dan faktual dapat dipotret secara utuh dalam pembentukan Naskah Akademik.

Menurut ketentuan umum Pasal 1 angka 11 Undang-Undang Nomor 12 Tahun 2011 tentang Pembentukan Peraturan PerundangUndangan mendefinisikan bahwa Naskah Akademik adalah naskah hasil penelitian atau pengkajian hukum dan hasil penelitian lainnya terhadap suatu masalah tertentu yang dapat dipertanggungjawabkan secara ilmiah mengenai pengaturan masalah tersebut dalam suatu Rancangan Undang-Undang, Rancangan Peraturan Daerah Provinsi, atau Rancangan Peraturan Daerah Kabupaten/Kota sebagai solusi terhadap permasalahan dan kebutuhan hukum masyarakat. Untuk mendapatkan kualitas perancangan peraturan daerah maka dalam perumusannya perlu memperhatikan kaidah penyusnan Naskah Akademik.

Sistematika baku penyusunan Naskah Akademik dalam proses pembentukan Rancangan Peraturan Daerah dimaksud mengacu pada amanat Undang-Undang Nomor 12 Tahun 2011 tentang Pembentukan Peraturan Perundang-Undangan terdiri dari 6 (enam) bab antara lain:

BAB I PENDAHULUAN berisi Pendahuluan, memuat latar belakang, sasaran yang akan diwujudkan, identifikasi masalah, tujuan dan kegunaan, serta metode penelitian. (1) Latar belakang memuat pemikiran dan alasan-alasan perlunya penyusunan Naskah Akademik sebagai acuan pembentukan Rancangan Peraturan Daerah tertentu. Latar belakang menjelaskan mengapa pembentukan Rancangan Peraturan Daerah memerlukan suatu kajian yang mendalam dan komprehensif mengenai teori atau pemikiran ilmiah yang berkaitan dengan materi muatan Rancangan Peraturan Daerah yang akan dibentuk. Pemikiran ilmiah tersebut mengarah kepada penyusunan argumentasi filosofis, sosiologis serta yuridis guna mendukung perlu atau tidak perlunya penyusunan Rancangan Peraturan Daerah. (2) Identifikasi masalah memuat rumusan mengenai masalah apa yang akan ditemukan dan diuraikan dalam Naskah Akademik tersebut. Pada dasarnya identifikasi masalah dalam suatu Naskah Akademik mencakup 4 (empat) pokok masalah, yaitu sebagai berikut:

a) Permasalahan apa yang dihadapi dalam kehidupan berbangsa, bernegara, dan bermasyarakat serta bagaimana permasalahan tersebut dapat diatasi.

b) Mengapa perlu Rancangan Peraturan Daerah sebagai dasar pemecahan masalah tersebut, yang berarti membenarkan pelibatan negara dalam penyelesaian masalah tersebut.

c) Apa yang menjadi pertimbangan atau landasan filosofis, sosiologis, yuridis pembentukan Rancangan Peraturan Daerah.

d) Apa sasaran yang akan diwujudkan, ruang lingkup pengaturan, jangkauan, dan arah pengaturan.

Tujuan dan Kegunaan Kegiatan Penyusunan Naskah Akademik sesuai dengan ruang lingkup identifikasi masalah yang dikemukakan di atas, tujuan penyusunan Naskah Akademik dirumuskan sebagai berikut: (1) Merumuskan 
permasalahan yang dihadapi dalam kehidupan berbangsa, bernegara, dan bermasyarakat serta cara-cara mengatasi permasalahan tersebut. (2) Merumuskan permasalahan hukum yang dihadapi sebagai alasan pembentukan Rancangan Peraturan Daerah sebagai dasar hukum penyelesaian atau solusi permasalahan dalam kehidupan berbangsa, bernegara, dan bermasyarakat. (3) Merumuskan pertimbangan atau landasan filosofis, sosiologis, yuridis pembentukan Rancangan Peraturan Daerah. (4) Merumuskan sasaran yang akan diwujudkan, ruang lingkup pengaturan, jangkauan, dan arah pengaturan dalam Rancangan Peraturan Daerah. Sementara itu, kegunaan penyusunan Naskah Akademik adalah sebagai acuan atau referensi penyusunan dan pembahasan Rancangan Peraturan Daerah.

Berdasarkan uraian diatas maka penyusunan Naskah Akademik pada dasarnya merupakan suatu kegiatan penelitian, sehingga digunakan metode penyusunan Naskah Akademik yang berbasiskan metode penelitian hukum atau penelitian lain. ${ }^{19}$ Penelitian hukum dapat dilakukan melalui metode yuridis normatif dan metode yuridis empiris. Metode yuridis empiris dikenal juga dengan penelitian sosiolegal.
Metode penelitian Socio-legal adalah nama lain untuk istilah law and societies studies. Socio-legal studies adalah istilah generik untuk menyebutkan semua ilmu-ilmu sosial yang mempelajari hukum. Di dalam socio-legal studies terdapat sejumlah ilmu sosial seperti sosiologi hukum, antropologi hukum, sejarah hukum, politik hukum dan psikologi hukum. Dalam bahasa yang lain, socio-legal studies dianggap juga sebagai istilah generik untuk setiap pendekatan perspektif sosial terhadap hukum. Socio-legal studies berangkat dari asumsi bahwa hukumadalah sebuah gejala sosial yang terletak dalam ruang sosial dan dengan itu tidak bisa dilepaskan dari konteks sosial. Hukum bukanlah entitas yang sama sekali terpisah dan bukan merupakan bagian dari elemen sosial yang lain. Hukum tidak akan mungkin bekerja dengan mengandalkan kemampuannya sendiri sekalipun ia dilengkapi dengan perangkat asas, norma dan institusi. ${ }^{20}$

Hukum dapat dipelajari baik dari perspektif ilmu hukum atau ilmu sosial, maupun kombinasi diantara keduanya. Studi socio-legal merupakan kajian terhadap hukum dengan menggunakan pendekatan ilmu hukum maupun ilmu-ilmu sosial. Studi hukum dinegara berkembang 
memerlukan kedua pendekatan baik pendekatan ilmu hukum maupun ilmu sosial. Pendekatan dan analisis ilmu hukum diperlukan untuk mengetahui isi dari legislasi dan kasus hukum. Namun pendekatan ini tidak menolong memberi pemahaman tentang bagaimana hukum bekerja dalam kenyataan sehari-hari, dan bagaimana hubungan hukum dengan konteks kemasyarakatan. Atau 'bagaimana efektiftas hukum dan hubungannya dengan konteks ekologinya. Oleh karena itu dibutuhkan pendekatan interdisipliner, yaitu konsep dan teori dari berbagai disiplin ilmu dikombinasikan dan digabungkan untuk mengkaji fenomena hukum, yang tidak diisolasi dari konteks sosial, politik, ekonomi, budaya, di mana hukum itu berada. ${ }^{21}$

Metode yuridis normatif dilakukan melalui studi pustaka yang menelaah (terutama) data sekunder yang berupa Peraturan Perundangundangan, putusan pengadilan, perjanjian, kontrak, atau dokumen hukum lainnya, serta hasil penelitian, hasil pengkajian, dan referensi lainnya. Metode yuridis normatif dapat dilengkapi dengan wawancara, diskusi (focus group discussion), dan rapat dengar pendapat. Metode yuridis empiris atau sosiolegal adalah penelitian yang diawali dengan penelitian normatif atau penelaahan terhadap Peraturan Perundang-undangan (normatif) yang dilanjutkan dengan observasi yang mendalam serta penyebarluasan kuesioner untuk mendapatkan data faktor non hukum yang terkait dan yang berpengaruh terhadap Peraturan Perundang-undangan yang diteliti.
BAB II KAJIAN TEORETIS DAN PRAKTIK EMPIRIS. Dalam Bab ini memuat uraian mengenai materi yang bersifat teoretis, asas, praktik, perkembangan pemikiran, serta implikasi sosial, politik, dan ekonomi, keuangan negara dari pengaturan dalam suatu Peraturan Daerah Provinsi, atau Peraturan Daerah Kabupaten/Kota. Bab ini dapat diuraikan dalam beberapa sub bab berikut: (1) Kajian teoretis, (2) Kajian terhadap asas/ prinsip yang terkait dengan penyusunan norma. (3) Analisis terhadap penentuan asasasas ini juga memperhatikan berbagai aspek bidang kehidupan terkait dengan Peraturan Perundang-undangan yang akan dibuat, yang berasal dari hasil penelitian. (4) Kajian terhadap praktik penyelenggaraan, kondisi yang ada, serta permasalahan yang dihadapi masyarakat. (5) Kajian terhadap implikasi penerapan sistem baru yang akan diatur dalam Peraturan Daerah terhadap aspek kehidupan masyarakat dan dampaknya terhadap aspek beban keuangan negara/daerah.

BAB III EVALUASI DAN ANALISIS PERATURAN PERUNDANG-UNDANGAN TERKAIT. Dalam Bab ini memuat hasil kajian terhadap Peraturan Perundang-undangan terkait yang memuat kondisi hukum yang ada, keterkaitan Undang-Undang dan Peraturan Daerah baru dengan Peraturan Perundang-undangan lain, harmonisasi secara vertikal dan horizontal, serta status dari Peraturan Perundang-undangan yang ada, termasuk Peraturan Perundang-undangan yang dicabut dan dinyatakan tidak berlaku serta Peraturan Perundang-undangan yang masih tetap berlaku karena tidak bertentangan dengan

21 Adriaan W. Bedner, Kajian Sosio-Legal (Jakarta: Universitas Indonesia, Universitas Leiden, Universitas Groningen, 2012), hlm. 2. 
Undang-Undang atau Peraturan Daerah yang baru. Kajian terhadap Peraturan Perundangundangan ini dimaksudkan untuk mengetahui kondisi hukum atau peraturan perundangundangan yang mengatur mengenai substansi atau materi yang akan diatur. Dalam kajian ini akan diketahui posisi dari Peraturan Daerah yang baru. Analisis ini dapat menggambarkan tingkat sinkronisasi, harmonisasi Peraturan Perundangundangan yang ada serta posisi Peraturan Daerah untuk menghindari terjadinya tumpang tindih pengaturan. Hasil dari penjelasan atau uraian ini menjadi bahan bagi penyusunan landasan filosofis dan yuridis dari pembentukan Peraturan Daerah Provinsi, atau Peraturan Daerah Kabupaten/Kota yang akan dibentuk.

BAB IV LANDASAN FILOSOFIS, SOSIOLOGIS, DAN YURIDIS. (1) Landasan filosofis merupakan pertimbangan atau alasan yang menggambarkan bahwa peraturan yang dibentuk mempertimbangkan pandangan hidup, kesadaran, dan cita hukum yang meliputi suasana kebatinan serta falsafah bangsa Indonesia yang bersumber dari Pancasila dan Pembukaan Undang-Undang Dasar Negara Republik Indonesia Tahun 1945. (2) Landasan Sosiologis merupakan pertimbangan atau alasan yang menggambarkan bahwa peraturan yang dibentuk untuk memenuhi kebutuhan masyarakat dalam berbagai aspek. Landasan sosiologis sesungguhnya menyangkut fakta empiris mengenai perkembangan masalah dan kebutuhan masyarakat dan negara. (3) Landasan Yuridis merupakan pertimbangan atau alasan yang menggambarkan bahwa peraturan yang dibentuk untuk mengatasi permasalahan hukum atau mengisi kekosongan hukum dengan mempertimbangkan aturan yang telah ada, yang akan diubah, atau yang akan dicabut guna menjamin kepastian hukum dan rasa keadilan masyarakat. Landasan yuridis menyangkut persoalan hukum yang berkaitan dengan substansi atau materi yang diatur sehingga perlu dibentuk Peraturan Perundang-Undangan yang baru. Beberapa persoalan hukum itu, antara lain, peraturan yang sudah ketinggalan, peraturan yang tidak harmonis atau tumpang tindih, jenis peraturan yang lebih rendah dari Undang-Undang sehingga daya berlakunya lemah, peraturannya ada tetapi tidak memadai, atau peraturannya memang sama sekali belum ada.

BAB $\vee$ JANGKAUAN, ARAH PENGATURAN, DAN RUANG LINGKUP MATERI MUATAN PERATURAN DAERAH PROVINSI, ATAU PERATURAN DAERAH KABUPATEN/KOTA. Naskah Akademik pada akhirnya berfungsi mengarahkan ruang lingkup materi muatan Rancangan Peraturan Daerah Provinsi, atau Rancangan Peraturan Daerah Kabupaten/ Kota yang akan dibentuk. Bab ini, sebelum menguraikan ruang lingkup materi muatan, dirumuskan sasaran yang akan diwujudkan, arah dan jangkauan pengaturan. Materi didasarkan pada ulasan yang telah dikemukakan dalam bab sebelumnya. Selanjutnya mengenai ruang lingkup materi pada dasarnya mencakup (1) ketentuan umum memuat rumusan akademik mengenai pengertian istilah, dan frasa; (2) materi yang akan diatur; (3) ketentuan sanksi; dan (4) ketentuan peralihan.

BAB VI PENUTUP. Bab penutup terdiri atas sub bab simpulan dan saran. Simpulan memuat rangkuman pokok pikiran yang berkaitan dengan praktik penyelenggaraan, pokok elaborasi teori, dan asas yang telah diuraikan dalam bab sebelumnya. Saran memuat antara lain (1) Perlunya pemilahan substansi Naskah Akademik dalam suatu Peraturan Perundangundangan atau Peraturan Perundang-undangan 
di bawahnya. (2) Rekomendasi tentang skala prioritas penyusunan Rancangan Peraturan Daerah dalam Program Legislasi Daerah.

Pada poin terakhir harus dicantumkan daftar pustaka memuat buku, peraturan Perundangundangan, dan jurnal yang menjadi sumber bahan penyusunan Naskah Akademik untuk menghindarkan daripraktek plagiasi. Lebih lanjut dalam lampiran Naskah Akademik terdapat Rancangan Peraturan Daerah yang bersifat satu kesatuan. Dengan demikian untuk menguatkan pembentukan Rancangan Peraturan Daerah maka wajib dilakukan metode footnote pada pengaturan norma setiap bab, pasal, ayat apakah bersumber dari peraturan yang lebih tinggi sehingga bersifat mutatis mutandis pengaturannya. Metode dimaksud juga akan memudahkan dalam memberikan argumentasi hukum (ratio legis) maupun argumentasi akademik sebagai bentuk pertanggung jawaban ilmiah dalam proses pembahasan.

Perihal keberadaan Naskah Akademik dalam pembentukan Peraturan Daerah wajib hukumnya sebagai konsekuensi logis bahwa dalam proses legislasi harus memperhatikan pula pertimbangan maupun kaidah-kaidah akademik yang dapat di pertanggung jawabkan. Menurut hasil kajian yang dilakukan oleh The Habibie Center (THC) bekerja sama dengan Hans Seidel Foundation (HSF) Indonesia mengenai kualitas legislasi di Indonesia menunjukkan kondisi yang aktual terhadap pembentukan perundang-undangan. Berdasarkan executive summary diskusi, terdapat tujuh faktor yang mempengaruhi penurunan kualitas undangundang di Indonesia. Salah satu di antara tujuh faktor tersebut, terabaikannya Naskah Akademis (NA). Di dalam executive summary tersebut menegaskan bahwa: ${ }^{22}$

"Dengan NA, setidak-tidaknya suatu
rancangan undang-undang (RUU) dapat
dipertanggung-jawabkan secara ilmiah
terutama mengenai konsepsi yang berisi:
latar belakang, tujuan penyusunan,
sasaran yang ingin diwujudkan dan lingkup,
jangkauan objek atau arah pengaturan.
Bagaimanapun, dalam proses penyusunan
suatu RUU, NA merupakan potret atau peta
tentang berbagai hal atau permasalah yang
ingin dipecahkan melalui undang-undang
yang akan dibentuk atau disahkan".

Hal senada juga diutarakan oleh Yuliandri, ${ }^{23}$ bahwa dalam hubungan dengan asas-asas pembentukan peraturan perundang-undangan yang baik (algemene beginselen van behoorlijke regelgeving), khususnya asas tujuan yang jelas (het beginsel van duidelijke doelstelling) dan asas perlunya pengaturan (het noodzakelijkheids beginsel), serta asas dapat dilaksanakan (het beginsel van uitvoerbaarheid), dapat dikatakan bahwa penyusunan Naskah Akademik merupakan salah satu bentuk dari perwujudan asas-asas pembentukan peraturan perundangundangan yang baik. Bahkan dalam masa transisi demokrasi, kehadiran Naskah Akademik menjadi semakin penting. Hal ini ditegaskan pula oleh Ann dan Robert Siedman ${ }^{24}$ dalam bukunya Legislative Drafting for Democratic Social

\footnotetext{
22 The Habibie Center (THC) dan Hans Seidel Foundation (HSF), dalam Saldi Isra, Urgensi Naskah Akademik Dalam Penyusunan Peraturan Perundang-Undangan (makalah disampaikan dalam Diklat Legal Drafting Lembaga Administrasi Negara (LAN), di Pusat Diklat LAN, Jakarta, 18 Maret 2009).

23 Yuliandri, dalam Saldi Isra Ibid, hlm. 3.

24 Ann dan Robert Siedman dalam Saldi Isra, Ibid., hlm. 3.
} 
Change bahwa dalam proses pembentukan peraturan perundang-undangan research dan the concept paper menjadi kebutuhan yang tidak terelakkan. Dengan demikian, Naskah Akademik merupakan upaya untuk menjelaskan secara lebih terbuka kepada seluruh stakeholders tentang signifikansi kehadiran sebuah peraturan perundang-undangan.

\section{Pertanggung jawaban akademik dalam upaya penataan (restorasi) politik legislasi pembentukan Peraturan Daerah}

Dalam praktek, seringkali Naskah Akademis muncul setelah proses pembahasan peraturan perundang-undangan selesai dilaksanakan. Ke depan, perlu ditegaskan bahwa Naskah Akademik merupakan keharusan untuk mengusulkan perlunya peraturan perundangundangan baru atau perubahan terhadap peraturan perundang-undangan yang sudah ada. Hal ini dimaksudkan agar, ada konsekuensi hukum jika suatu rancangan peraturan perundang-undangan tidak disertai dengan Naskah Akademik.

Dalam proses pembentukan peraturan perundang-undangan, Naskah Akademik merupakan kumpulan argumentasi yang memenuhi standar-standar akademik. Menurut Jimly Asshiddiqie, ${ }^{25}$ sebagai suatu hasil kajian yang bersifat akademik, tentu NA sesuai dengan prinsip-prinsip ilmu pengetahuan, yaitu: rasional, kritis, objektif, dan impersonal. Karena itu, pertimbangan-pertimbangan yang melatar belakanginya tentulah berisi ide-ide normatif yang mengandung kebenaran ilmiah dan diharapkan terbebas dari kepentingankepentingan yang bersifat pribadi atau kelompok, kepentingan politik golongan, kepentingan politik kepartaian, dan sebagainya. Dengan Naskah Akademik, dapat dilihat bahwa setiap rancangan peraturan perundangundangan tidak disusun karena kepentingan sesaat, kebutuhan yang mendadak, atau karena pemikiran yang tidak mendalam. Dalam praktik, kebutuhan seperti ini menyebabkan sebuah peraturan perundang-undang lebih sering diubah dalam waktu singkat.

Dapat juga dikemukakan, mempersiapkan Naskah Akademik merupakan salah satu langkah penting dalam proses legislasi, karena NA berperan sebagai "quality control" yang sangat menentukan kualitas suatu produk hukum. Naskah Akademik memuat seluruh informasi yang diperlukan untuk mengetahui landasan pembuatan satu undang-undang yang baru, termasuk tujuan dan isinya. Kemudian, Naskah Akademik merupakan potret ataupun peta tentang berbagai hal terkait dengan peraturan perundang-undangan yang hendak diterbitkan. Tidak hanya itu, Naskah Akademik dapat juga berfungsi akan memberi arah kepada para pemangku kepentingan ("stake holders") dan perancang ("drafter"). Pemangku kepentingan, terutama yang menduduki posisi sebagai pengambil kebijakan akan mendapat informasi yang memadai dalam pengambilan keputusan. Sedangkan bagi perancang akan berfungsi sebagai acuan untuk dapat menentukan apa yang akan diatur dan diterjemahkan ke dalam kalimat hukum. ${ }^{26}$

Jimly Asshiddiqie dalam Saldi Isra, Ibid., hlm. 3.

26 Saldi Isra, Ibid., hlm. 3. 
Berdasarkan uraian diatas maka untuk menopang kualitas legislasi di daerah maka bentuk pendampingan mutlak dilakukan baik dari kalangan ahli maupun perguruan tinggi dengan komitmen untuk meningkatkan kualitas legislasi didaerah. Menurut penulis jika kualitas penyusunan legislasinya buruk sudah dipastikan pelayanan publik di daerah akan buruk dan potensi untuk terjadi penyimpangan dan korupsi akan besar. Oleh karena itu untuk membingkai pelaksanaan legislasi dalam pembentukan Rancangan Peraturan Daerah dapat dijabarkan melalui skema sebagai berikut: hukum. Yang terpenting dalam praktek penyusunan naskah akademik adalah kapasitas untuk mempertanggung jawabkan secara ilmiah dokumen yang telah dibentuk. Kondisi obyektif dalam kajian tentunya merupakan suatu bentuk kebenaran ilmiah yang akan memberikan dasar bagi para pengambil kebijakan untuk melakukan pilihan politik yang dianggap sebagai dasar pengaturan yang terbaik bagi pembangunan dan peningkatan kesejahteraan masyarakat disuatu daerah baik pada tingkat Provinsi, Kabupaten/Kota.

Skema 1 Pentahapan Penyusunan Rancangan Peraturan Daerah

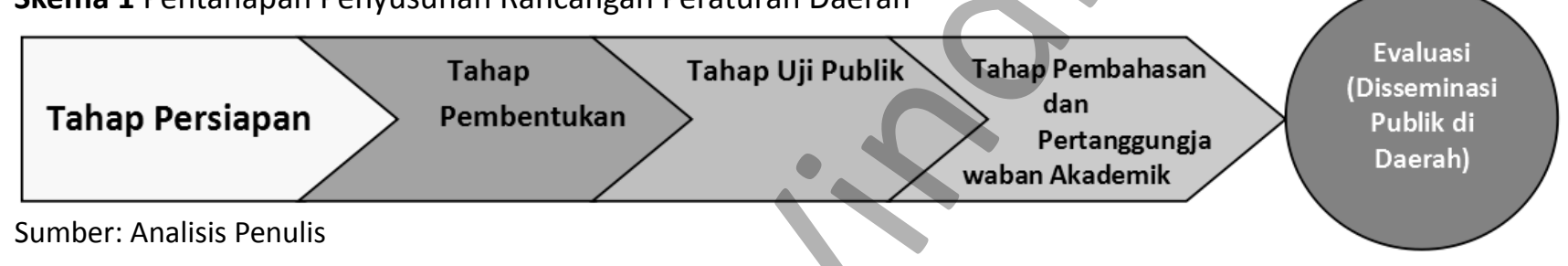

Berdasarkan pada skema diatas maka, dalam penelitian Naskah Akademik dimaksudkan pula pada basis akademik untuk menganalisis terhadap peraturan perundang-undangan harus bersifat berkelanjutan (sustainable). Hal ini bisa dipahami bahwa proses penyusunan Raperda ke dalam Prolegda maupun pembentukan produk hukum yang lainnya tidak semata-mata mencerminkan kebutuhan masyarakat akan tetapi juga memberhatikan aspek political will dari pemerintah selaku pengambil kebijakan untuk mendorong regulasi yang akan dibentuk. Dasar paradigmatik dari sistem perundangundangan yang memiliki corak keberlanjutan adalah adanya dokumen akademik atau dalam istilah hukum dikenal dengan adanya keberadaan Naskah Akademik (NA). Di dalam Naskah akademik sebagai dimaksud merupakan kerangka konseptual terkait dengan isu hukum (legal issue) dan model penelitian yang akan dilakukan tatkala menyusun sebuah produk

\section{E. Penutup}

\section{Kesimpulan}

Berdasarkan pembahasan diatas, maka secara kualitas legislasi masih menunjukkan adanya kondisi kelemahan dalam proses pembentukan Peraturan Daerah khususnya yang menyangkut pengaturan di bidang retribusi daerah, pajak daerah, investasi, maupun pelayanan dasar di daerah. Oleh karena itu praktek politik legislasi dalam proses pembentukan Rancangan Peraturan Daerah berbasis riset merupakan suatu kemutlakan untuk melahirkan Peraturan daerah yang berkualitas dan memiliki dasar keabsahan baik secara yuridis maupun akademik. Pelembagaan Naskah Akademik kedepan tidak sematamata ditempatkan pada kerangka prosedural formal sebagai dokumen pelengkap semata dalam proses pembahasan di DPRD (baik pada tingkat Provinsi, Kabupaten/Kota) akan 
tetapi merupakan suatu dokumen yang memiliki kesinambungan dan kesatuan prinsip dasar kajian dalam pembentukan Rancangan Peraturan daerah yang dapat dipertanggung jawabkan secara akademik.

\section{Rekomendasi}

Berdasarkan pembahasan diatas, maka dapat direkomendasikan antara lain: (1) untuk menunjang kinerja legislasi di daerah (baik pada tingkat Provinsi, Kabupaten/Kota) maka praktek-praktek pendampingan dalam proses legislasi diperlukan keterlibatan perguruan tinggi maupun tenaga ahli (peneliti) untuk berkolaborasi dalam memberikan pengawalan dalam proses penyusunan Naskah Akademik dengan komitmen dan pakta integritas untuk memajukan kualitas legislasi diera otonomi daerah; (2) untukmenjamin adanya pertanggung jawaban akademik suatu kajian hukum maupun kajian penelitian lainnya sebagaimana amanat Undang-Undang Nomor 12 Tahun 2011 tentang Pembentukan Peraturan Perundang-Undangan maka diperlukan adanya disseminasi hasil kajian akademik kepada publik pada proses pembentukan hukum (law making process) di daerah agar dapat menjamin pelaksanaan prinsip publisitas sehingga pelaksanaanya akan efektif guna mendorong berbagai aspek pembangunan dan pelayanan publik di daerah.

\section{DAFTAR PUSTAKA}

\section{Buku}

Arrsa, Ria Casmi dkk, Teori dan Hukum Perancangan Perda (The Turning Point Of Legal Paradigm on Sustainaible Development) (Malang: UB Press, 2012).

Astawa, I Gede Pantja, Problematika Hukum Otonomi Daerah di Indonesia, (Bandung: Alumni, 2008).

Bedner, Adriaan W, Kajian Sosio-Legal, (Jakarta: Universitas Indonesia, Universitas Leiden, Universitas Groningen, 2012).
B.N Marbun, Kamus Politik, (Jakarta: Pustaka Sinar Harapan, 2007).

Friedman, Lawrence M., Teori Sistem Hukum (Bandung: Penerbit Nusamedia, 2011).

Karim, Adbul Gafur, Kompleksitas Persoalan Otonomi Daerah di Indonesia, (Yogyakarta: Pustaka Pelajar, 2003).

Kementerian PPN/Bappenas RI, Pedoman Penerapan Reformasi Regulasi, (Jakarta: Kementerian PPN/ Bappenas, 2011).

Kusumaatmadja, Mochtar, Konsep-Konsep Hukum Dalam Pembangunan (Kumpulan Karya Tulis) (Bandung: Penerbit Alumni, 2002).

Sumadi, Ahmad Fadlil, Politik Hukum, Konstitusi, dan Mahkamah Konstitusi (Aktualisasi Konstitusi Dalam Praksis Kenegaraan), (Malang: Intrans Publishing: 2013).

Sumarwoto, Otto, Ekologi, Lingkungan Hidup, dan Pembangunan, (Jakarta: Penerbit Jembatan, Cetakan Ketiga, 1997).

Wahab, Solichin, A, Masa Depan Otonomi Daerah (Kajian Sosial, Ekonomi, Politik, Untuk Menciptakan Sinergi Dalam Pembangunan Daerah), (Surabaya: Penerbit SIC, 2002).

Wahyono, Padmo, Sistem Hukum Nasional Dalam Negara Hukum Pancasila (Jakarta: CV. Rajawali, 1983).

\section{Makalah / Artikel / Prosiding / Hasil Penelitian}

Asshidiqie, Jimly, "Otonomi Daerah Dan Parlemen Di Daerah" (Makalah Disampaikan dalam "Lokakarya tentang Peraturan Daerah dan Budget Bagi Anggota DPRD se-Propinsi (baru) Banten" yang diselenggarakan oleh Institute for the Advancement of Strategies and Sciences (IASS), di Anyer, Banten, 2 Oktober 2000.

Atmasasmita, Romli, "Menata Kembali Masa Depan Pembangunan Hukum Nasional" (Makalah disampaikan dalam "Seminar Pembangunan Hukum Nasional VIII" di Denpasar, 14-18 Juli 2003).

Fadli, Moh, "Penguatan Fungsi Legislasi DPRD" (makalah untuk Simposium Nasional Satu Dasawarsa Pelaksanaan Otonomi Daerah diselenggarakan oleh PP-OTODA FH UB, Malang, 1-2 Desember 2010).

Isra, Saldi, "Urgensi Naskah Akademik Dalam Penyusunan Peraturan Perundang-Undangan" (Makalah disampaikan dalam Diklat Legal Drafting Lembaga Administrasi Negara (LAN), di Pusat Diklat LAN, Jakarta, 18 Maret 2009). 
Pambudi, P, Agung, Perda dan Hambatan Investasi, Jurnal Hukum Jentera, Edisi XIV Tahun IV Oktober-Desember (2006).

Pusat Pengembangan Otonomi Daerah (PPOTODA), "Pemetaan Kualitas Legislasi di Jawa Timur" (Laporan disampaikan dalam Diklat Legislative Drafting Bagi Aparatur Pemerintah Daerah dan DPRD Se Jawa Timur, 1 Oktober 2012 di ruang Auditorium lantai VI Fakultas Hukum Universitas Brawijaya).

Rikardo Simarmata, "Socio-Legal Studies dan Gerakan Pembaharuan Hukum", Digest Law, Society \& Development, Volume I (Desember 2006-Maret 2007).

\section{Internet}

Mulyadi, Lilik, Teori Hukum Pembangunan Prof. Dr. Mochtar Kusumaatmadja, S.H., LL.M., Makalah diakses dari http://www.legalitas.org, (diakses tanggal 1 Maret 2013).

http://www.kemendagri.go.id

\section{Peraturan}

Undang-Undang Dasar Negara Republik Indonesia Tahun 1945

Undang-Undang Nomor 32 Tahun 2004 Tentang Pemerintahan Daerah (Lembaran Negara Republik Indonesia Tahun 2004 Nomor 125, Tambahan Lembaran Negara Republik Indonesia Nomor 4437) sebagaimana telah diubah beberapa kali terakhir dengan Undang-Undang Nomor 12 Tahun 2008 tentang Perubahan Kedua atas Undang-Undang Nomor 32 Tahun 2004 tentang Pemerintahan Daerah (Lembaran Negara Republik Indonesia Tahun 2008 Nomor 59, Tambahan Lembaran Negara Republik Indonesia Nomor 4844);

Undang-Undang Nomor 12 Tahun 2011 Tentang Pembentukan Peraturan Perundang-Undangan (Lembaran Negara Republik Indonesia Tahun 2011 Nomor 82, Tambahan Lembaran Negara Republik Indonesia Nomor 5234).

Peraturan Menteri Dalam Negeri Nomor 53 Tahun 2011 tentang Pembentukan Produk Hukum Daerah. 